\title{
Can Macroeconomic Variables Explain Long Term Stock Market Movements? A Study of Nepali Capital Market
}

\author{
Niranjan Phuyal* \\ Nepal Stock Exchange Limited, Kathmandu, Nepal
}

\begin{abstract}
The quest of whether there is a long-run relation between macroeconomic variables and stock prices has found significant place in literature of finance. An existence of such relation would assure longterm investors a confidence in the market as long as the macroeconomic environment is sound. This study investigated using Johansen's cointegration method, whether a long-term association of selected macroeconomic variables existed with stock prices in the emerging market like Nepali stock market. For this objective, monthly data from January 2003 to December 2012 were used with a set of six macroeconomic variables and stock market return. The results indicated that the Nepali stock market had a long run equilibrium relationship with a set of macroeconomic variables, like inflation rate, interest rate and remittance flow with the short term disequilibrium corrected by $1.79 \%$ on monthly basis. It further showed that there was Granger causality between them. In the short run, the stock market index was affected by the lag values of NEPSE index up to six levels and remittance income, as shown by Wald test. These findings hold practical implications for policy makers, stock market regulators, investors and stock market analysts.
\end{abstract}

Keywords: Co-integration, macroeconomic variables, stock return, Johansen-Juselius co-integration, vector error correction model, Wald test

\section{Introduction}

Economic growth of Nepal during the last five decades has not been very impressive when compared with that of other neighboring countries. Within this period, Nepal has gone through a number of transformations at political front. The liberalized economic policy initiated in the 1980s continued in the decade of 90 s after the restoration of democracy. During this decade, the country implemented a number of key liberal reforms like deregulation of trade, industry, finance, and foreign exchange regimes; streamlining of price controls and subsidies; privatization of key public enterprises; massive reductions in trade related tariffs; and policy related to industry and foreign investment (ADB, DFID, \& ILO, 2009). However, political instability due to the frequent government changes and Maoists insurgency after 1995 delayed implementation and completion of some of the more difficult reforms, and hence weakened its economic growth.

One of the agendas of the economic reform was to develop an efficient capital market in Nepal. For the formal structure of capital market, Securities Board of Nepal (SEBON) as the apex regulator of

* Author Email: niranjan@kusom.edu.np 
the capital market and Nepal Stock Exchange (NEPSE) as a secondary market operator were established in 1993.Twenty years have passed but the Nepali capital market is still considered an infant as it is not in the leading role for the mobilization of savings toward investment.

Emerging stock markets are partially segmented from global capital markets. Therefore, local factors rather than global factors should be the primary source of the movement in stock returns in these markets. In the Nepali context, the Gross Domestic Product (GDP) growth for last few years has hardly crossed 5\%. In fiscal year (FY) 2007-08, it was 6.1\% and for the rest of the period it remained below 5\% whereas the inflation rate remained around 10\% during the period (Nepal Rastra Bank [NRB], 2012). Similarly, percentage increase in the Nepali export was negative in the FYs 2006-07, 2007-08 and 2009-10 and was marginally positive in the rest of the years. However, the increasing trend of import was in double digit percent with the highest of 31.6\% in FY 2009-10. On the other hand, Nepali financial market faced extreme liquidity crisis during the period of FYs 2008-09 to 201112 which pushed the interest rate to the highest point. During the same period, indicators of capital market showed high volatility.

Since the establishment till 2012, NEPSE Index witnessed various ups and downs with two major collapses in 2000 and 2009. In the continuous decreasing trend of market from 2008 to 2011, NEPSE Index lost 883 points and reached to 292 from 1175 (Nepal Stock Exchange, 2011). Likewise, the market capitalization has also decreased by around 50\%. In each collapse, thousands of stock market investors lost significant amount of their wealth, and a large majority of them accumulated some degree of financial debt, which caused many social complaints.

Previous studies like Fama (1981), Geske and Roll (1983), and Chen, Roll, and Ross (1986), among others, have indicated a link between increased price volatility in the stock market to the movement of macroeconomic variables. Therefore, it is important to explore similar relationships between the Nepali stock market and the set of macroeconomic variables. The main objective of this study is to observe whether macroeconomic factors individually and/or collectively contribute to the dynamics of the Nepali stock market.

Over the past few decades, stock markets in the emerging economies have surged with growing attention of the investors around the world. Prior studies on the determinants of stock return primarily focused on the well-developed markets with less attention given to the emerging markets. Empirical testing of the theory from the emerging markets would be important for finance literature.

The capital market is considered a barometer of an economy. Although the macroeconomic variables are moving positively in a slow pace with less volatility, the indicators in capital market of Nepal were too volatile during the last decade. Such indicators started to increase rapidly from the FY 2005-06 and declined remarkably after FY 2008-09. This hinted that macroeconomic factors in the Nepali economy might not be properly harmonized with the capital market. This situation posed a question whether macroeconomic variables like remittances, money supply, prices, and interest rate in the Nepali economy could be used to describe short-run and long-run equilibrium relationships with the stock market. Therefore, this paper examined co-integration of the selected six macroeconomic variables with the stock market returns and tried to check how efficient the Nepali stock market was to raise the required capital for the economy. 


\section{Literature Review}

Many studies have used stock price to find out the impact of macroeconomic variables on the stock market return. Gan, Lee, Yong, and Zhang (2006) employed Johansen and Juselius's (1990) cointegration approach, Granger causality tests, and impulse response analysis to determine whether the New Zealand Stock Index was a leading indicator for a set of seven macroeconomic variables that included money in circulation (M1), short term interest rate, long term interest rate, inflation rate, Consumer Price Index (CPI), exchange rates, GDP, and the domestic retail price of oil. Evidence from the study suggested that a long run relationship existed between New Zealand's stock index and the aforementioned seven macroeconomic variables.

Maysami, Howe, and Hamzah (2004) used monthly data from January 1989 to December 2001 to examine the relationship between Singapore's composite stock index and three Singapore sector indexes (the finance index, the property index, and the hotel index) with macroeconomic variables. These variables were CPI, proxies for long and short-run interest rates; money supply (M2); and exchange rates. Based on the results of Johansen's co-integration test, the Singapore stock market and property index showed a significant long-run relationship with all macroeconomic variables included in the analysis. Similarly, Rahman and Mustafa (2008) studied the long-run and short-run dynamic effects of broad money supply (M2) and price of oil on S\&P 500 using monthly data from January 1974 to April 2006. The results provided support in favor of the three variables being co-integrated.

Some other studies have focused on developing countries. One of them was by Ahmed (2008) which investigated the nature of the long and short run relationships between Indian stock prices and a set of macroeconomic variables using quarterly data over the period from March 1995 to March 2007. These variables were money supply, interest rates, exports, foreign direct investment, exchange rates, primary stock index of the National Stock Exchange in India, and the Bombay Stock Exchange index. Johansen and Juselius's (1990) co-integration approach, the causality test, Forecast Error Variance Decomposition (FEVD) analysis, and Impulse Response Function (IRFs) analysis were used. The findings revealed that a long run relationship existed between stock prices and money supply and there existed only a short run relationship between interest rate and stock return. Another study by Hasan and Javed (2009) explored the long-term relationship between Pakistan equity prices and monetary variables using data from June 1998 to June 2008. The monetary variables included money supply, treasury bill rate, foreign exchange rates, and CPI. The Johansen-Juselius (1990) co-integration test provided evidence of a long run relationship and unidirectional Granger causality between equity market and monetary variables. Likewise, impulse response analysis indicated that both interest rate and exchange rate shocks have negative impact on equity returns, whereas the money supply has positive impact.

Several key conclusions can thus be drawn. First, there exists a short term and long term link between macroeconomic variables and stock markets. Second, the previous studies have significantly improved our understanding of the relationships between financial markets and real economic activity, the findings from the literature are mixed given that they are sensitive to the choice of countries, variable selection, and the time period studied. Therefore, it is difficult to generalize the results because each market is unique in terms of its own rules, regulations, and type of investors. Third, the vector auto-regression (VAR) framework, co-integration test, and Granger causality tests are commonly used to examine the relationships between stock prices and real economic activity. 


\section{Methods}

This section deals with the data and methodology adopted for the completion of this study. At first, the variables used in the study are described and then the nature and sources of data with its time period are explained. Finally, the method of data analysis with the related model is presented.

\section{Variables Used}

The various variables that have been identified in the literature as important determinants of stock returns are taken for analysis in this study. The first one is the CPI which is used to examine the long run relation of inflation to the stock market return. Abdullah and Hayworth (1993), Dhakal, Kandil, and Sharma (1993), Gan et al. (2006), Maysami et al. (2004) and Hasan and Javed (2009) were among many who used CPI to describe the stock market return. Similarly, money supply, as one of the independent variables to discuss about the stock return was used by many scholars like Abdullah and Hayworth (1993), Dhakal at al. (1993), Darrat (1990), Gan et al. (2006), Maysami et al. (2004) and Rahman and Mustafa (2008). In this study M1 definition of money is used as the money supply variable.

Foreign exchange rate (FER) is widely used (see Darrat, 1990; Gan et al., 2006; Maysami et al., 2004) as an independent variable to study the impact on stock price. The average monthly exchange rate of the Nepali currency with the United States Dollar, calculated by NRB is used in this study. Fama and Schwert (1977) and Abdullan and Hayworth (1993) used short term interest rate (I) as one of the independent variables to define the impact on stock return and observed significant negative relationship. A fall in interest rates reduces the costs of borrowing and encourages investment. Moreover, investment in the secondary market is also fueled by lower interest rate and thus it affects the share price. Hence, changing interest rate has greater influence on stock market variability. For this study, the average rate of 91-day Treasury bill quoted by NRB was used as the proxy for short term interest rate which is very widely used short-term risk free instrument in Nepal. Total remittance (REM) amount during the fiscal year 2012-13 consists of more than 35 percent of total GDP (Nepal Rastra Bank, 2013). Remittances received from different countries are the main source of positive balance of payment. The liquidity in Nepali banking sector is mainly determined by the remittance volume received (Nepal Rastra Bank, 2012). So, the amount of remittance received each month is taken as a factor to affect the stock return and hypothesized that they will bear positive relationship. Capital market index, NEPSE, is used as a proxy to calculate market return (RM).

\section{Nature and Sources of Data}

The study was based on secondary data. The sources of data were NEPSE, SEBON, NRB, and Ministry of Finance (MOF). Information on major macro-economic variables was collected from NRB and Central Bureau of Statistics. Similarly, some of the selected variables like CPI, money supply, interest rate, exchange rate and remittance were collected from the publication of NRB. The study used monthly data from January 1, 2003 to December 31, 2012.

Market return was calculated thus using NEPSE index,

$$
R M_{t}=\operatorname{Ln}\left(\frac{\operatorname{Index}_{t}}{\operatorname{Index}_{(t-1)}}\right) .
$$


Index $\mathrm{x}_{\mathrm{t}}$ is the month end NEPSE index; Index $\mathrm{t}_{\mathrm{t}-1}$ is the NEPSE index of previous month; and Ln refers to the natural log. Similar method was used to calculate the monthly inflation rate from CPI, foreign exchange rate is month end rate of US Dollar in Nepali currency. The monthly risk free rate of return is 91-day treasury bill rate published in the monthly National Debt Bulletin of NRB.

\section{Econometric Method}

In time series data, the issue of stationary is an important character because regression on nonstationary variables can be spurious. However, co-integration provides a way to examine whether seemingly spurious regression is spurious or not. In this study, to carry out the co-integration, Johansen-Juselius (1990) co-integration test has been used. The following procedures have been followed:

(i) The stationary characteristic in the time series was substantiated by performing the augmented Dickey - Fuller (ADF) test. This test was conducted on the variables in level and first differences.

(ii) When VAR model is used, it is essential to determine the optimal lag length for the VAR system, which is performed by using criteria, the final prediction error criteria (FPE), the Akaike information criterion (AIC), the Schwarz information criterion (SIC), and the Hannan-Quinn information criterion (HQ), and modified likelihood ratio (LR). AIC was used when different lags were selected (Erdugan, 2012).

(iii) Johansen and Juselius (1990) approach was applied to test for co-integration.

(iv) A vector error correction model (VECM) of the following type was used. The model was applied in order to investigate short and long run dynamic adjustment of defined system of co-integrated variables.

$$
\Delta Y_{t}=\delta+\sum_{i=1}^{p} \Gamma \Delta Y_{t-i}+\prod_{i} Y_{t-i}+v_{t}
$$

Where $\mathrm{Y}_{\mathrm{t}}$ is a vector of variables, $Y_{t}=$ (NEPSE Index, CPI, FER, REM, M, IR), a $6 \times 1$ vector of variables and $\delta$ is a vector of constants. $\Pi$ is the error correction mechanism, which has two components: $\Pi=\alpha \times \beta$ ' where $\alpha$ is a column vector representing the speed of short run adjustment, and $\beta^{\prime}$ is a co-integrating vector with matrix of long run coefficients. $\Gamma$ is a matrix representing the coefficients of the short run dynamics. Finally, $v_{t}$ is a vector of white noise error term, and $\mathrm{p}$ is the order of auto-regression.

\section{Results}

The set of macroeconomic variables included the NEPSE index, CPI, M, FER, interest rate (IR), and REM.

\section{Descriptive Statistics}

Positive values of the skewness tests for CPI, IR, M, NEPSE and REM suggested that these variables have long right tails. As the value of kurtosis for CPI, M and REM was less than 3, their distribution was flatter than a normal distribution which meant the values have wider spread around their mean. The kurtosis for IR was larger than 3 which meant the values concentrated around its mean. 
Table 1

Statistical Features of the Macroeconomic Variables

\begin{tabular}{lrrrrrr}
\hline & CPI & FER & IR & M & NEPSE & REM \\
\hline Mean & 171.53 & 72.07 & 0.00 & 560932.70 & 502.38 & 13767.97 \\
$\quad$ Median & 163.90 & 71.84 & 0.00 & 483642.00 & 422.51 & 12116.20 \\
Maximum & 236.0 & 84.16 & 0.01 & 1059903.00 & 1175.38 & 29986.20 \\
Minimum & 119.0 & 63.12 & 0.00 & 295215.90 & 226.72 & 4893.90 \\
CV & 0.27 & 0.08 & 1.02 & 0.44 & 0.49 & 0.61 \\
Skewness & 0.29 & 0.00 & 0.62 & 0.62 & 0.90 & 0.37 \\
Kurtosis & 1.70 & 3.29 & 2.29 & 2.07 & 3.02 & 1.95 \\
Jarque-Bera & 7.57 & 0.32 & 7.61 & 9.04 & 12.04 & 6.21 \\
Probability & 0.02 & 0.85 & 0.02 & 0.01 & 0.00 & 0.04 \\
Observations & 120 & 120 & 120 & 96 & 120 & 114 \\
\hline
\end{tabular}

Table 2 showed correlation between the variables and indicated strong positive relation (above 0.8 ) between M and CPI, REM and CPI, and M and REM. Moreover, correlation coefficient between NEPSE and FER was negative.

Table 2

Correlation Matrix of the Macroeconomic Variables

\begin{tabular}{lllllll}
\hline \multicolumn{1}{c}{1} & \multicolumn{1}{c}{2} & 3 & 4 & 5 \\
\hline 1 & CPI & & & & & \\
2 & FER & $.35^{* *}$ & & & & \\
3 & IR & $.59 * *$ & $.00^{* *}$ & & & \\
4 & M & $.98^{* *}$ & $.38^{* *}$ & $.57 * *$ & & \\
5 & NEPSE & $.13^{* *}$ & $-.33^{* *}$ & .19 & .02 & $.14 *$ \\
6 & REM & $.95^{* *}$ & $.45^{* *}$ & $.58^{* *}$ & $.95^{* *}$ & .14 \\
\hline
\end{tabular}

Note: $\mathrm{p}<.05 ; \mathrm{p}<.01$

Unit Root Test Result

Determining the order of integration for each variable included in the system was the first step to understanding the long-run relationship among these variables. For this, the augmented Dickey-Fuller (ADF) unit root test was used with the following three alternative models:

$$
\begin{aligned}
& \Delta Y_{t}=\alpha_{0}+\alpha_{1} t+\gamma Y_{t-1}+\sum_{i=1}^{p} \beta_{i} \Delta Y_{t-1}+\varepsilon_{t} \\
& \Delta Y_{t}=\alpha_{0}+\gamma Y_{t-1}+\sum_{i=1}^{p} \beta_{i} \Delta Y_{t-1}+\varepsilon_{t} \ldots \ldots \ldots \\
& \Delta Y_{t}=\gamma Y_{t-1}+\sum_{i=1}^{p} \beta_{i} \Delta Y_{t-1}+\varepsilon_{t} \ldots \ldots \ldots \ldots \ldots \ldots
\end{aligned}
$$

Where, $\mathrm{Y}$ is each macroeconomic variable, $\alpha_{i}$ and $\gamma$ are constant terms while $\mathrm{t}$, and $\Delta$ are the time trend and the first difference operator respectively. $\varepsilon_{i}$ is the white noise residual and $p$ is the optimal lagged values of $\Delta Y$. To test for stationarity, the null hypothesis is $\mathrm{H}_{0}: \gamma=0$, which means the series is non-stationary (presence of unit root). 
Table 3

ADF Unit Root Test for the All Variables

\begin{tabular}{|c|c|c|c|c|c|c|}
\hline & \multicolumn{3}{|c|}{ Data at Level } & \multicolumn{3}{|c|}{ Data at First Difference } \\
\hline & $t$-Statistics & $\begin{array}{l}\text { Optimum } \\
\text { Lag }\end{array}$ & $p$-value & $t$-Statistics & $\begin{array}{l}\text { Optimum } \\
\text { Lag }\end{array}$ & $p$-value \\
\hline \multicolumn{7}{|c|}{ Panel (a): Model with intercept \& trend } \\
\hline CPI & -2.08 & 7 & .55 & -8.77 & 6 & .00 \\
\hline FER & -2.03 & 1 & .58 & -8.11 & 0 & .00 \\
\hline IR & -2.94 & 0 & .15 & -12.73 & 0 & .00 \\
\hline M & -1.28 & 0 & .89 & -11.13 & 0 & .00 \\
\hline NEPSE & -1.20 & 4 & .91 & -7.02 & 3 & .00 \\
\hline REM & -1.57 & 1 & .80 & -10.29 & 1 & .00 \\
\hline \multicolumn{7}{|c|}{ Panel (b): Model with intercept only } \\
\hline CPI & 2.50 & 7 & 1.00 & -8.00 & 6 & .00 \\
\hline FER & -1.38 & 1 & 0.59 & -7.96 & 0 & .00 \\
\hline IR & -2.96 & 0 & 0.06 & -12.77 & 0 & .00 \\
\hline M & 2.69 & 0 & 1.00 & -10.08 & 0 & .00 \\
\hline NEPSE & -1.38 & 4 & 0.59 & -7.08 & 3 & .00 \\
\hline REM & 1.83 & 2 & 1.00 & -9.89 & 1 & .00 \\
\hline \multicolumn{7}{|c|}{ Panel (c): Model without intercept \& trend } \\
\hline CPI & 6.48 & 7 & 1.00 & -5.20 & 0 & .00 \\
\hline FER & 0.31 & 1 & 0.79 & -7.97 & 0 & .00 \\
\hline IR & -1.72 & 0 & 0.08 & -12.82 & 0 & .00 \\
\hline M & 6.44 & 0 & 1.00 & -2.84 & 2 & .01 \\
\hline NEPSE & -0.01 & 4 & 0.68 & -7.00 & 3 & .00 \\
\hline REM & 3.15 & 2 & 1.00 & -13.66 & 0 & .00 \\
\hline
\end{tabular}

Table 3 reported the results of ADF test on the above three models. The upper limit of the laglength was determined based on the AIC criteria. The null hypothesis of non-stationarity could not be rejected for all macroeconomic variables at their levels. Application of the same test to their first differences showed that the null hypothesis of unit root was rejected in all cases. Therefore it was concluded that the macroeconomic variables at their levels were integrated of order one. The same result was observed in all three models.

\section{Johansen-Juselius Co-integration Test}

The second step for establishing the presence of a long-run relationship among the variables was to determine the optimal lag length for the VAR system. Lag-length misspecification for the VAR model often generates autocorrelated errors (Lutkepohl, 2005). Lag length was determined by using the following five criteria. Table 4 reported the results for all criteria with a maximum of 8 lags. Out of the different criteria, AIC, FPE and LR suggested using the maximum lag of six. ${ }^{1}$

Upon determining the optimal lag length, the next step was to apply co-integration test and estimate the appropriate co-integrating vectors using the above variables.

\footnotetext{
${ }^{1}$ The AIC-specified lag lengths almost always did better than the other criterion (Enders, 2010; Lutkepohl, 2005).
} 
Table 4

VAR Lag Order Selection Criteria

\begin{tabular}{cccclll}
\hline Lag & Log L & LR & FPE & AIC & SC & HQ \\
\hline 0 & -3132.46 & NA & $6.39 \mathrm{e}+24$ & 71.31 & 71.45 & 71.36 \\
1 & -2586.99 & 1016.55 & $4.66 \mathrm{e}+19$ & 59.48 & $60.32^{*}$ & 59.82 \\
2 & -2539.68 & 82.79 & $2.82 \mathrm{e}+19$ & 58.97 & 60.52 & $59.59^{*}$ \\
3 & -2520.59 & 31.24 & $3.27 \mathrm{e}+19$ & 59.10 & 61.36 & 60.01 \\
4 & -2492.41 & 42.91 & $3.13 \mathrm{e}+19$ & 59.03 & 61.99 & 60.22 \\
5 & -2454.78 & 53.02 & $2.45 \mathrm{e}+19$ & 58.75 & 62.40 & 60.22 \\
6 & -2425.40 & $38.06^{*}$ & $2.37 \mathrm{e}+19 *$ & $58.64^{*}$ & 63.01 & 60.40 \\
7 & -2405.42 & 23.61 & $2.93 \mathrm{e}+19$ & 58.76 & 63.83 & 60.80 \\
8 & -2376.53 & 30.86 & $3.07 \mathrm{e}+19$ & 58.67 & 64.44 & 60.99 \\
\hline
\end{tabular}

Note: * lag order selected by the criterion

Table 5

Johansen-Juselius Co-integration Test

(Variables Used: NEPSE, CPI, IR, REM)

\begin{tabular}{|c|c|c|c|c|c|}
\hline \multicolumn{6}{|c|}{ Panel (a): Restricted Co-integration Rank Based on Trace Statistic Test } \\
\hline \multicolumn{2}{|c|}{ Hypothesized no. of CE(s) } & \multirow[t]{2}{*}{ Eigenvalue } & \multirow{2}{*}{$\begin{array}{c}\text { Trace } \\
\text { Statistics }\end{array}$} & \multirow{2}{*}{$\begin{array}{l}0.05 \text { critical } \\
\text { value }\end{array}$} & \multirow[t]{2}{*}{$p$-value } \\
\hline Null & Alternative & & & & \\
\hline$r=0$ & $r \geq 1$ & 0.25 & 59.82 & 47.86 & $.00^{*}$ \\
\hline$r \leq 1$ & $r \geq 2$ & 0.17 & 29.18 & 29.80 & .06 \\
\hline$r \leq 2$ & $r \geq 3$ & 0.08 & 9.12 & 15.49 & .35 \\
\hline$r \leq 3$ & $r \geq 4$ & 0.00 & 0.14 & 3.84 & .71 \\
\hline
\end{tabular}

Trace test indicates 1 co-integrating equation at the 0.05 level

\begin{tabular}{|c|c|c|c|c|c|}
\hline \multicolumn{6}{|c|}{ Panel (b) Restricted Co-integration Rank Test Based on Max Eigenvalue Test } \\
\hline \multirow{2}{*}{\multicolumn{2}{|c|}{$\begin{array}{l}\text { Hypothesized no. of CE(s) } \\
\text { Null Alternative }\end{array}$}} & \multirow[t]{2}{*}{ Eigenvalue } & \multirow{2}{*}{$\begin{array}{l}\text { Max-Eigen } \\
\text { Statistic }\end{array}$} & \multirow{2}{*}{$\begin{array}{l}0.05 \text { critical } \\
\text { value }\end{array}$} & \multirow[t]{2}{*}{$p$-value } \\
\hline & & & & & \\
\hline$r=0$ & $r \geq 1$ & 0.249 & 30.643 & 27.584 & $0.020 *$ \\
\hline$r \leq 1$ & $r \geq 2$ & 0.171 & 20.062 & 21.132 & 0.070 \\
\hline$r \leq 2$ & $r \geq 3$ & 0.081 & 8.982 & 14.265 & 0.288 \\
\hline$r \leq 3$ & $r \geq 4$ & 0.001 & 0.136 & 3.841 & 0.713 \\
\hline
\end{tabular}

Note: Max-eigenvalue test indicates 1cointegrating equation at the 0.05 level; the null hypothesis is that there is no co-integration; " $r$ " is the number of co-integrating relationship; * rejection of the null hypothesis at the $5 \%$ level

The primary results of Johansen-Juselius co-integration tests showed that there were two cointegrating equations. But to perform the VECM, it would be better to have only one. So, restriction was imposed among the variables. After restricting one by one, it was found that while restricting FER and $\mathrm{M}$, the result of Johansen Juselius Co-integration test showed that there was only one vector as proven by both trace test and maximum eigenvalue test. The result for the remaining variables NEPSE, CPI, IR and REM is presented in Table 5. 
The co-integrating equation meant that there existed a linear combination of the group of macroeconomic variables with NEPSE index that ensured them to have a long run convergence. Moreover, if two or more time-series are co-integrated, then there must be Granger causality between them - either one-way or in both directions (Erdugan, 2012). However, the converse is not true. In particular, NEPSE, CPI, IR and REM were found to be moving together towards a stable long-run equilibrium that was consistent with causality running in both directions.

Table 6 showed the estimated coefficients of the co-integrating equation. The co-integrating vector could not be identified unless some arbitrary normalization was imposed. The normalized cointegrating relation was given by:

\section{NEPSE -91.30 CPI - 152915.8 IR + 0.67 REM}

It was tested whether macroeconomic variables were significant in the co-integrating vector normalized on stock prices with the aid of a likelihood ratio test. The t-statistics suggested that macroeconomic variables entered significantly in the co-integrating vector.

The VECM estimates provided important information about the short run relationship between stock return and macroeconomic variables as well as the speed of adjustment towards the long run equilibrium level. The VECM equation is:

$$
\Delta X_{t}=\delta_{i}+\sum_{i=1}^{p} \Gamma \Delta X_{t-1}+\Pi X_{t-1}+v_{t}
$$

Where $\mathrm{p}=6$, variable $\mathrm{X}_{\mathrm{t}}$ stands for NEPSE, CPI, IR and REM.

The above equation has two channels of causation. The first channel is through the lagged exogenous variables' coefficients. The second channel of causation is through the error correction term (ECT).

Table 6

Normalised Co-integrating Coefficients

Co-integrating Equation: $\quad$ Log likelihood $\quad-1219.41$

Normalized co-integrating coefficients (standard error in parentheses)

\begin{tabular}{cccc}
\hline NEPSE & CPI & IR & REM \\
\hline 1.00 & -91.30 & -152915.80 & 0.67 \\
& $(24.93)$ & $(88231.20)$ & $(0.16)$ \\
& {$[-3.67]$} & {$[-1.73]$} & {$[4.22]$} \\
\hline
\end{tabular}

Note: Standard errors in parenthesis and t-values in square brackets

The estimated VECM equation (6) is presented in Table 7. The first coefficient, $\mathrm{C} 1$, is the coefficient of error correction term of the co-integrated model. It is also the speed of adjustment that corrects NEPSE from its deviation away from long-run equilibrium. It showed that the deviation from the long run equilibrium was corrected at the rate of $1.79 \%$ per month which also meant NEPSE would converge to its long-run equilibrium path. The result in Table 8 showed that the lag variables of changes in NEPSE, IR and REM had short term influence on stock market return. 
Table 7

Output of the VECM Equation

\begin{tabular}{|c|c|c|c|}
\hline Coefficient & Variable name & Coefficient Value & $p$-value \\
\hline $\mathrm{C}(1)$ & ECT & -0.02 & .00 \\
\hline $\mathrm{C}(2)$ & NEPSE lag 1 & 0.05 & .63 \\
\hline $\mathrm{C}(3)$ & NEPSE lag 2 & 0.21 & .05 \\
\hline $\mathrm{C}(4)$ & NEPSE lag 3 & -0.13 & .22 \\
\hline $\mathrm{C}(5)$ & NEPSE lag 4 & -0.42 & .00 \\
\hline$C(6)$ & NEPSE lag 5 & 0.00 & .98 \\
\hline $\mathrm{C}(7)$ & NEPSE lag 6 & 0.05 & .62 \\
\hline $\mathrm{C}(8)$ & CPI lag 1 & -0.86 & .67 \\
\hline $\mathrm{C}(9)$ & CPI lag 2 & 3.38 & .15 \\
\hline $\mathrm{C}(10)$ & CPI lag 3 & 0.60 & .79 \\
\hline $\mathrm{C}(11)$ & CPI lag 4 & -3.13 & .16 \\
\hline $\mathrm{C}(12)$ & CPI lag 5 & 3.25 & .15 \\
\hline $\mathrm{C}(13)$ & CPI lag 6 & -3.01 & .13 \\
\hline $\mathrm{C}(14)$ & IR lag 1 & -3115.62 & .03 \\
\hline $\mathrm{C}(15)$ & IR lag 2 & -4044.98 & .01 \\
\hline $\mathrm{C}(16)$ & IR lag 3 & -4375.08 & .01 \\
\hline $\mathrm{C}(17)$ & IR lag 4 & -2925.34 & .06 \\
\hline $\mathrm{C}(18)$ & IR lag 5 & -3686.64 & .02 \\
\hline $\mathrm{C}(19)$ & IR lag 6 & -1949.18 & .16 \\
\hline $\mathrm{C}(20)$ & REM lag 1 & 0.02 & .00 \\
\hline $\mathrm{C}(21)$ & REM lag 2 & 0.01 & .00 \\
\hline $\mathrm{C}(22)$ & REM lag 3 & 0.01 & .02 \\
\hline $\mathrm{C}(23)$ & REM lag 4 & 0.01 & .06 \\
\hline $\mathrm{C}(24)$ & REM lag 5 & 0.01 & .05 \\
\hline $\mathrm{C}(25)$ & REM lag 6 & 0.01 & .07 \\
\hline $\mathrm{C}(26)$ & constant & -14.01 & .07 \\
\hline$R^{2}$ & 0.45 & Mean dependent var & 1.83 \\
\hline Adjusted $R^{2}$ & 0.28 & S.D. dependent var & 49.78 \\
\hline S.E. of regression & 42.17 & Akaike info criterion & 10.53 \\
\hline Sum squared residual & 145840.30 & Schwarz criterion & 11.17 \\
\hline Log likelihood & -542.48 & Hannan-Quinn criter. & 10.79 \\
\hline F-statistic $(\mathrm{p}<.01)$ & 2.68 & Durbin-Watson stat & 2.08 \\
\hline
\end{tabular}

The Wald test was used to find out whether lag independent variables jointly influenced the stock return or not. The null hypothesis was that the lag variables of independent variables and the NEPSE itself had no short term influence on stock return. The summary of the result is presented in Table 8 .

From the Wald test it could be concluded that there was a short term joint effect on stock return of 6 lag values of NEPSE index and remittance income. It showed that although there was long term cointegration between macroeconomic variables and stock market return, only lag value of remittance had short term influence on stock market. 
The existence of a long run relation between NEPSE Index and macroeconomic variables like CPI, REM and IR is consistent with a large body of empirical studies, including Gan et al. (2006), Hasan and Javed (2009), Humpe and Macmillan (2007), and Maysami et al. (2004). The results further indicated Granger causality between them. Moreover, the Wald test showed that changes in NEPSE index and remittance income up to six lags would have impact on stock index changes in the short run.

Table 8

Effect on NEPSE return of lagged values of variables

\begin{tabular}{llrrrr}
\hline \multirow{2}{*}{$\begin{array}{c}\text { Lag } \\
\text { Variable }\end{array}$} & Null & \multicolumn{2}{c}{$F$ Statistic } & \multicolumn{2}{c}{ Chi-Square } \\
\cline { 3 - 6 } NEPSE & $\mathrm{C}(2)=\mathrm{C}(3)=\mathrm{C}(4)=\mathrm{C}(5)=\mathrm{C}(6)=\mathrm{C}(7)=0$ & 3.56 & .00 & 21.38 & .00 \\
\hline $\mathrm{CPI}$ & $\mathrm{C}(8)=\mathrm{C}(9)=\mathrm{C}(10)=\mathrm{C}(11)=\mathrm{C}(12)=\mathrm{C}(13)=0$ & 1.33 & .25 & 7.97 & .24 \\
\hline IR & $\mathrm{C}(14)=\mathrm{C}(15)=\mathrm{C}(16)=\mathrm{C}(17)=\mathrm{C}(18)=\mathrm{C}(19)=0$ & 1.76 & .12 & 10.57 & .10 \\
\hline REM & $\mathrm{C}(20)=\mathrm{C}(21)=\mathrm{C}(22)=\mathrm{C}(23)=\mathrm{C}(24)=\mathrm{C}(25)=0$ & 3.51 & .00 & 21.06 & .00 \\
\hline
\end{tabular}

\section{Discussion}

In this study, the long and short run dynamic relationships between NEPSE index and six other macroeconomic variables over the period from January 2003 to December 2012 were examined. The macroeconomic variables were money supply, short term interest rate, CPI, remittance and exchange rate. The investigation of stationary property of time series data showed that all six variables were nonstationary in their level and stationary in first difference. Johansen and Juselius' co-integration method was applied to the VECM model that included NEPSE, CPI, IR and REM as level variables.

The data analysis indicated that the three macroeconomic variables, CPI, interest rate and remittance income, have not only long term equilibrium relation with the stock market index, but their changes are also the cause for changes in stock price. The variables like foreign exchange rate and money supply did not fit into such relationship. It provided an answer to the issue raised at the beginning that macroeconomic variables were co-integrated with the stock market and they were also partially the causes for the change in the stock market return. It further showed that there was a significant negative relation between consumer price index and NEPSE index whereas a significant positive relationship between NEPSE index and remittance income.

The VECM model showed that in the short run any disequilibrium from long-run will be corrected by $1.79 \%$ monthly. Similarly, the Wald test showed that the lag value up to six lag of NEPSE return and changes in remittance income have short term influence on the stock return. In conclusion, there is a long term association between these four variables, and such a relation can be used to predict the stock price in the long run.

The issue raised earlier in this study was about the harmonization of macroeconomic situation with stock market indicators. The stock market was established to facilitate the economic development through capital market (GC \& Neupane, 2006). The co-integration test showed some of the selected macroeconomic variables, namely interest rate, consumer price index and remittance, shared a long run relationship with the stock market. Similar results have been revealed by many other co-integration studies done on relation between macroeconomic variables and stock market return (for example, Abdullah \& Hayworth, 1993; Ahmed, 2008; Billmeier \& Massa, 2007; Darrat, 1990; Erdugan, 2012). Darrat (1990), for example, found a long term relation of monetary policy variables in Canadian stock 
market, with short term interest rate and inflation being the most influential factors to affect the stock return. Similarly, Abdullah and Hayworth (1993) found that lag coefficient of stock return itself had linkage with the current stock return and inflation was the prime factor to affect stock return. The study by Billmeier and Massa (2007) was one of such few studies which had evaluated the long term association of remittance income and stock market return and found out that they had a significant long term relationship. As Nepali economy is hugely affected by remittance income, and its spills on liquidity in financial sector, the result of long term co-integration of remittance and stock return isconvincing. But most studies conducted on macroeconomic variables to impact stock return have not included remittance, as it may not be contributing to their national economy.

\section{Implications and Future Research Directions}

This research contributes to the assets pricing theory in finance literature regarding the emerging stock markets. The findings of this paper are important for finance academics and practitioners. It may also be useful to the investors of the Nepali stock market to analyze the macroeconomic factors that affect the stock market return in both short and long terms.

Some implications of these findings are: (i) the stock market price movement can be predicted in the long run by using macroeconomic variables,(ii) investors in the Nepali stock market should look at the systematic risks revealed by the short term interest rates, inflation and remittance income when structuring portfolios and diversification strategies; and (iii) while formulating economic and financial policies like monetary policy, policies about interest rate in the economy and the inflation rate, the concerned regulators and policymakers may take into consideration the long term association between these macroeconomic variables and the stock market return.

In general, return in the Nepali stock market has a long term association with a few macroeconomic variables like interest rate, inflation rate and remittance income during the study period of 2003 to 2012. Since the Nepali stock market is relatively very small comparing with other emerging markets, it may not be appropriate to generalize the results for all the emerging markets. In future, similar studies can be extended to incorporate other relatively bigger emerging markets so that it can be generalized.

Similarly, this study is limited to only a few selected macroeconomic variables. Thus, inclusion of more macroeconomic variables like GDP, industrial production, sector wise market return, etc. with a longer time period may improve the results. In addition, future research can be conducted by using additional econometric techniques such as ARDL approach to co-integration, Impulse Response Functions, Forecast Error Variance Decompositions which may provide additional strength to the conclusion of the research study and help to forecast for the future.

\section{References}

Abdullah, D. A., \& Hayworth, S. C. (1993). Macroeconometrics of stock price. Quarterly Journal of Business and Economics, 32(1),50-67.

ADB, DFID, \& ILO. (2009). Nepal: Critical development constraints. Mandaluyong City, Philippines: Asian Development Bank.

Ahmed, S. (2008). Aggregate economic variables and stock market in India. International Research

Journal of Finance and Economics, 14, 141-164. 
Billmeier, A., \& Massa, I. (2007). What drives stock market development in the middle east and central Asia-institutions, remittances, or natural resources?Venice,Italy: International Monetary Fund. Retrieved from http://www.imf.org/external/pubs/ft/wp/2007/wp07157.pdf

Chen, N.-F., Roll, R., \& Ross, S. A. (1986). Economic forces and stock market. Journal of Business, 59(3),383-403. http://dx.doi.org/10.1086/296344

Darrat, A. F. (1990). Stock returns, money, and fiscal deficits. The Journal of Financial and Quantitative Analysis, 25(3),387-398. http://dx.doi.org/10.2307/2330703

Dhakal, D., Kandil, M., \& Sharma, S. C. (1993). Causality between the money supply and share prices: A VAR investigation. Journal of Business and Economics, 32(3),52-74.

Enders, W. (2010). Applied econometric time series(3rd ed.). New York, NY: John Wiley \& Sons.

Erdugan, R. (2012). The effect of economic factors on the performance of the Australian stock market. Melbourne, Australia: Faculty of Business and Law, Victoria University.

Fama, E. F. (1981). Stock returns, real activity, inflation, and money. American Economic Review, 71(4),545-565. http://dx.doi.org/10.1016/0304-405X(77)90014-9

Fama, E. F., \& Schwert, G. W. (1977). Asset returns and inflation. Journal of Financial Economics, 5,115-146.

Gan, C., Lee, M., Yong, H. H., \& Zhang, J. (2006). Macroeconomic variables and stock market interactions: Newzearland evidence. Investment Management and Financial Innovations, 3(4),89101.

GC, S. B., \& Neupane, S. (2006). Stock market and economic development: A causality test. The Journal of Nepalese Business Studies, 3(1), 36-44.

Geske, R., \& Roll, R. (1983). The fiscal and monetary linkage between stock returns and inflation. Journal of Finance, 38(1),7-33. http://dx.doi.org/10.1111/j.1540-6261.1983.tb03623.x

Hasan, A., \& Javed, M.T. (2009). An empirical investigation of the causal relationship among monetary variables and equity market returns. The Lahore Journal of Economics, 14(1),115-137.

Humpe, A., \& Macmillan, P. (2007). Can macroeconomic variables explain long term stock market movements?A comparison of the U.S. and Japan (CDMA Working Paper No. 07/20). St Andrews,England: University of St Andrews.

Johansen, S., \& Juselius, K. (1990). Maximum likehood estimation and inference on cointegration With applications to the demand for money. Oxford Bulletin of Economics and Statistics, 52(2),169-210. http://dx.doi.org/10.1111/j.1468-0084.1990.mp52002003.x

Lutkepohl, H. (2005). New introduction to multiple time series analysis. Berlin, Germany: Springer. http://dx.doi.org/10.1007/978-3-540-27752-1

Maysami, R. C., Howe, L. C., \& Hamzah, M. A. (2004). Relationship between macroeconomic variables and stock market indices: Cointegration evidence from stock exchange of Singapore's all sector indices. Jurnal Pengurusan, 24,44-77.

Nepal Stock Exchange. (2011). Annual trading report 2010-11. Kathmandu, Nepal: Author.

Nepal Rastra Bank. (2012). Macro economic indicator of Nepal. Kathmandu, Nepal: Author.

Nepal Rastra Bank. (2012). Financial staiblity report. Kathmandu, Nepal: Author.

Nepal Rastra Bank. (2013). Economic survey. Kathmandu, Nepal: Author.

Rahman, M., \& Mustafa, M. (2008). Influences of money supply and oil price on US stock market. North American Journal of Finance and Banking, 2(2),1-12. 